\title{
DEVELOPMENT AND VALIDATION OF ANLYTICAL METHODS FOR THE SIMULTANEOUS ESTIMATION OF LORNOXICAM AND PARACETAMOL FROM THEIR PHARMACEUTICAL DOSAGE FORM
}

\author{
Patel $\mathrm{A}^{*^{3}}$. Patel $\mathrm{N}^{1}$. Patel $\mathrm{M}^{2}$. Lodha $\mathrm{A}^{3}$. Chaudhuri $\mathrm{J}^{3}$. Jadia $\mathrm{P}^{3}$. Joshi $\mathrm{T}^{3}$. Dalal $\mathrm{J}^{3}$. \\ ${ }^{1}$ Parul Institute of Pharmacy, Limda, Waghodia. Baroda, 361760, Gujarart, India \\ ${ }^{2}$ Baroda College of Pharmacy Limda, Waghodia. Baroda, 361760, Gujarat, India \\ ${ }^{3}$ Gujarat Liqui Pharmacaps Pvt. Ltd. 662-666, GIDC, Waghodia, Baroda, 361760, Gujarart, India.
}

\begin{abstract}
A simple Reverse phase liquid chromatographic method has been also developed and subsequently validated for simultaneous determination of Paracetamol and Lornoxicam in combination. The separation was carried out using a mobile phase consisting of Potassium dihydrogen phosphate, $\mathrm{pH}$ adjusted to 7.3 with triethyl amine and acetonitrile 70:30(\%v/v).The column was used Phenomex $\mathrm{C}_{18}, 5 \mu \mathrm{m},(250 \mathrm{x} 4.6 \mathrm{~mm})$ with flow rate $1.5 \mathrm{ml} / \mathrm{min}$ using UV detection at $257 \mathrm{~nm}$. The described method was linear over concentration range 20 to $60 \mu \mathrm{g} / \mathrm{ml} \& 0.2$ to $1.8 \mu \mathrm{g} / \mathrm{ml}$ for assay of Paracetamol \& Lornoxicam respectively. The retention time of Paracetamol \& Lornoxicam were found to be 2.33 \& 7.61 respectively. Result of analysis was validated statistically. The method show good reproducibility \& recovery with $\%$ less than 1 , all the tests of above mentioned studies were found to be in acceptance criteria.The method was found to be rapid, specific, precise \& accurate and can be successfully applied for routine analysis of Paracetamol \& Lornoxicam in bulk \& combined dosage forms.
\end{abstract}

Keywords: Paracetamol, Lornoxicam, HPLC

\section{INTRODUCTION}

Paracetamol (PARA), chemically 4-hydroxy acetanilide, is a centrally and peripherally acting non-opioid analgesic and antipyretic ${ }^{1-3}$. Literature survey reveals, there are UV and HPLC methods reported for the estimation of PARA in Pharmaceutical formulations.

Lornoxicam (LOX) is 6-chloro-4-hydroxy-2-methyl-N-2-pyridinyl-2H-thieno-[2,3-e]-1,2-thiazine-3-carboxamide 1,1dioxide; is a novel non-steroidal anti-inflammatory drug (NSAID) with marked analgesic properties. LOX belongs to the chemical class oxicams, which includes piroxicam,tenoxicam and meloxicam. LOX, which is commercially available as an 8$\mathrm{mg}$ tablet, is used to treat inflammatory diseases of the joints, osteoarthritis, and pain after surgery. It works by blocking the action of cyclooxygenase, an enzyme involved in the production of chemicals, including some prostaglandins in the body ${ }^{1-5}$. Extensive literature survey reveals, none of the method is available that is based on estimation of

Paracetamol and Lornoxicam by HPLC. Aim of present work was to develop simple, precise, accurate and economical HPLC methods for simultaneous determination of binary drug formulation.

The proposed method was optimized and validated in accordance with International Conference on Harmonization (ICH) guidelines ${ }^{6-9}$

MATERIALS \& METHOD

Apparatus: Sonicator, Shimadzu 2010(Auto injector), pH Meter, Beaker, Volumetric Flask.

Reagent: Water (HPLC Grade), Potassium Dihydrogen Phosphate, Triethylamine, Acetonitrile(HPLC Grade), API Lornoxicam \& Paracetamol.

$\begin{array}{lcc}\text { Experimental Chromatographic Conditions } \\ \text { Stationary phase } & : & \text { Phenomex, } 5 \mu \mathrm{m}, \mathrm{C}_{18}(250 \times 4.6 \mathrm{~mm}) \text { column } \\ \text { Mobile phase } & : & 21 \mathrm{mM} \text { potassium dihyrogen phosphate (pH adjusted to } 7.3 \text { with Triethyl amine): } \\ & & \text { acetonitrile } \\ \text { Solvent ratio } & : & 70: 30 \% \mathrm{v} / \mathrm{v} \\ \mathrm{pH} & : & 7.3 \\ \text { Detection wavelength } & : & 257 \mathrm{~nm}\end{array}$


IOSR Journal of Pharmacy

Vol. 2, Issue 3, May-June, 2012, pp. 364-366

$\begin{array}{lll}\text { Flow rate } & : & 1.5 \mathrm{ml} / \text { minute } \\ \text { Operating pressure } & : & 158 \mathrm{kgf} \\ \text { Temperature } & : & \text { Room temperature }\end{array}$

Validation Parameters of RP-HPLC

\begin{tabular}{|l|l|l|}
\hline Parameters & Paracetamol & Lornoxicam \\
\hline LOD (Detection limit) (ng/ ml) & $0.5 \mu \mathrm{g}$ & $10 \mu \mathrm{g}$ \\
\hline LOQ (Quantitation limit) (ng/ ml) & $10 \mu \mathrm{g}$ & $20 \mu \mathrm{g}$ \\
\hline Accuracy (\%) & $\begin{array}{l}50 \%-99.24 \% \\
100 \%-98.92 \%\end{array}$ & $\begin{array}{l}50 \%-101.01 \\
100 \%-100.84 \%\end{array}$ \\
\hline $\begin{array}{l}\text { Tailing Factor } \\
\text { (NMT 2) }\end{array}$ & 1.312 & 1.283 \\
\hline $\begin{array}{l}\text { Precision (\%RSD) } \\
\text { (NMT 2) }\end{array}$ & - & - \\
& & \\
\hline Intra-day (n=3) & 0.2045 & 1.3560 \\
\hline Inter-day (n=3) & 0.1944 & 1.3662 \\
\hline Repeatability of injection (\%RSD) & 0.0919 & 0.7860 \\
\hline Robustness & $\begin{array}{l}\text { Meets } \\
(\mathrm{RSD} \text { of } 6 \text { replicates: } \\
\leq 2 \%)\end{array}$ & $\begin{array}{l}\text { Meets } \\
\text { (RSD of 6 replicates: } \\
\leq 2 \%)\end{array}$ \\
\hline
\end{tabular}

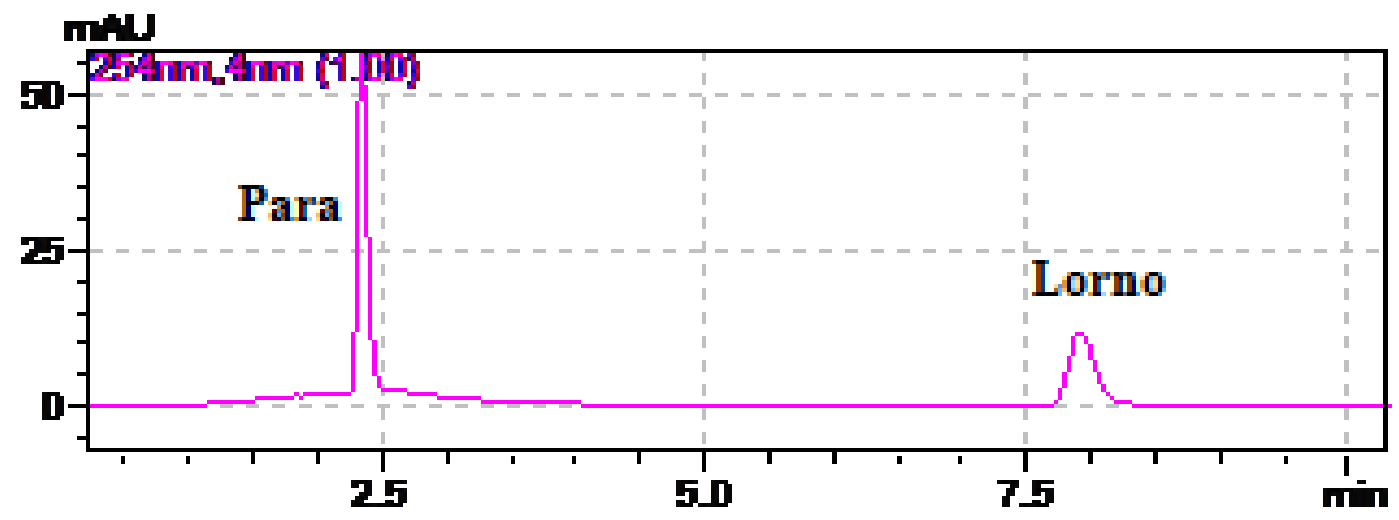

\section{ANALYSIS OF FORMULATION:}

Preparation of standard solution:

$100 \mathrm{mg}$ of Paracetamol and $1.6 \mathrm{mg}$ of Lornoxicam diluted with the Mobile phase up to $100 \mathrm{ml}$ (Stock Solution). 
IOSR Journal of Pharmacy

Vol. 2, Issue 3, May-June, 2012, pp. 364-366

Make $100 \mu \mathrm{g} / \mathrm{ml}$ of Paracetamol and $1.6 \mu \mathrm{g} / \mathrm{ml}$ of Lornoxicam diluted with the Mobile phase.

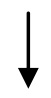

Aliquots of standard solutions containing $25 \mu \mathrm{g} / \mathrm{ml}$ of Paracetamol and $0.4 \mu \mathrm{g} / \mathrm{ml}$ of Lornoxicam.

Preparation of sample solution

20 tablets $\longrightarrow$ Average weight $\longrightarrow$ Powdered \& weighed a quantity equivalent

to $100 \mathrm{mg}$ of Paracetamol and $1.6 \mathrm{mg}$ of Lornoxicam were transferred to $100 \mathrm{ml}$ standard flask and make up with the with mobile phase.

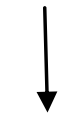

Aliquots of solutions containing $25 \mu \mathrm{g} / \mathrm{ml}$ of Paracetamol and 0.4 $\mu \mathrm{g} / \mathrm{ml}$ of Lornoxicam diluted with mobile phase.

\section{Analysis of formulation}

\begin{tabular}{|l|l|l|l|l|}
\hline \multirow{2}{*}{ Drug } & \multicolumn{2}{|l|}{ Amount $(\boldsymbol{\mu g} /$ tablet) } & \% label claim & \multirow{2}{*}{ \% RSD* } \\
\cline { 2 - 5 } & Labeled & Estimated & & \\
\hline Para & 25 & 24.85 & 99.40 & 0.2581 \\
\hline Lorno & 0.4 & 0.39 & 97.50 & 0.3214 \\
\hline
\end{tabular}

\section{CONCLUSION}

Para - paracetamol, Lorno - Lornoxicam

The developed assay method was found to be simple, accurate, sensitive, précised, and rapid. This method can be applied for routine quantitative analysis of Paracetamol and Lornoxicam in pharmaceutical formulations like Tablet dosage form.

\section{REFERENCES}

1. Available online at: http://en.wikipedia.org/wiki/Lornoxicam.htm on $6^{\text {th }}$ August 2010.

2. Available online at: http://en.wikipedia.org/wiki/Paracetamol.htm on $6^{\text {th }}$ August 2010.

3. Ramesh Sawant, Lokesh Bhangale, Rupali Joshi and Prashant Lanke. Validated spectrophotometric methods for simultaneous estimation of Paracetamol, Domperidone and Tramadol $\mathrm{HCl}$ in pure and tablet dosage form. Journal of Chemical Metrology. 2010; 21-27

4. Mahesh Attimarad. Rapid RP HPLC Method for Quantitative Determination of Lornoxicam in Tablets. Journal of Basic and Clinical Pharmacy. May 2010.

5. Vrajesh Kansara, Sathesh Babu. Study the solubility of lornoxicam in different solvents using different concentration in tablet formulation. Journal of Basic and Clinical Pharmacy. May 2010.

6. International Conference on Harmonization of Technical Requirement for Registration of Pharmaceutical for Human use. Stability Testing of New Drug Substance and Products ICH Q1A (R2). 2003.

7. Chandran S, Singh RSP. Comparision of various international guidelines for analytical method validation. Pharmazie 2007; 62:4-14.

8. International Conference on Harmonization of Technical Requirement for Registration of Pharmaceuticals for Human use. Validation of Analytical Procedure: Text and Methodology ICH Q2 (R1). 2005.

9. ICH QIA (R2). Stability Testing of New Drug Substances and Products. 2003. 